\title{
農業埭象から夕た八戸の山背風
}

\author{
羽生 寿 郎・山田幸兵衛
}

(青森県農事試験場)

Yamase-wind at Hachinohe from the agricultural meteorological standpoints.

J. HANYU and K. YAMADA

(Aomori Agricultural experiment Station)

\section{に. まえがき}

青森県では北東寄りの風のことを山背風（ヤマセ）と 呼んでいるが，夏期の山背風は低温をるたらすので農業 上重大な関心がもたれている。山背風については木村1 及び著者の一人2)によつて昭和 24 年以来逐年調查が行 われて招り, 又門脇3) 回観測の資料から山背風の気候特性を論じたが，山背風 以外の風との比較がない。著者らは八户の牟和 12〜26 年の 15 ケ年間の，4月から 9 月京での午前 10 時に䑙 る気象資料から山背風の気候特性を明かにし, 且凶冷年 括ける気温と山背風との関係について報告する。

\section{2. 風向別気象}

風向を 16 方位と静㩊に分汀風向による気衷の特異性 る明かにすれば，山北風の䉇囲と気售特性が分る。本報 告では簢単のため 5 月から8月采での平均状態てついて の文述べる。

(1) 頻 度 第 1 図実線に示すように頻度に 2 つの 山が女り, NE, ENE, E と SW, WSW の風が多い。 頻度は全風向の出現日数に対する各風向の日数の割合を 旺分率で表している。

（2）気温15 ケ年間の日平均気温では佮山山があ るので5日移動平均をとつて日平均気湿とし, それから の気温偏差を風向每に平均与ると第 2 図実線のよ5にな り，低温風の範囲は NNW-(E)-SEであることが分 る。今仮にこの範团を山背風として扔く。

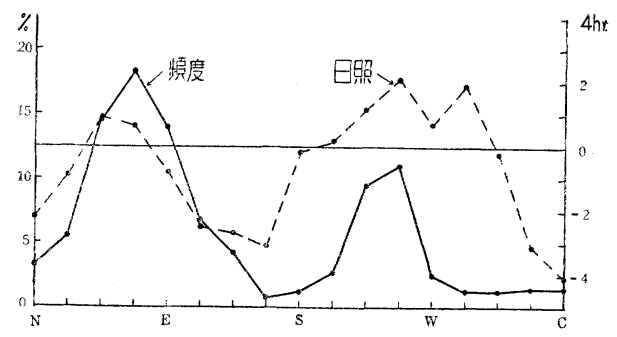

風向

第 1 図頻度及び日照時数の平年からの平均偏差

昭和 28 年 5 月 4 日, 28 年度総会にて発表

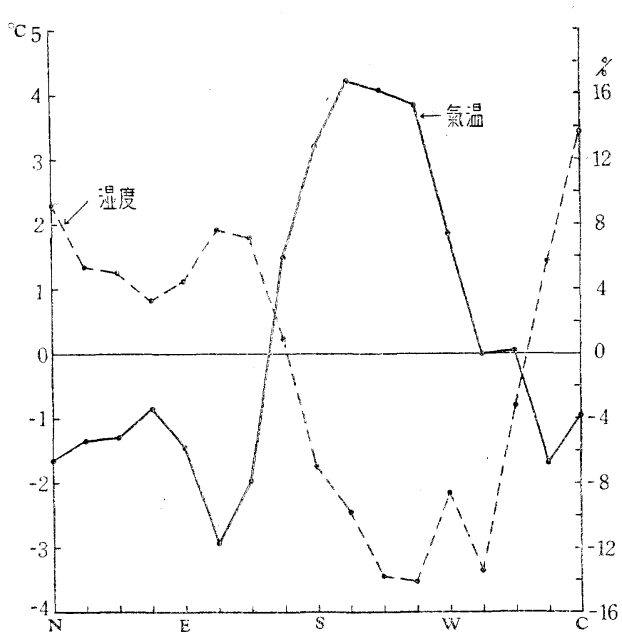

風向

第 2 図気温及び湿度の平年からの平均偏差

$\mathrm{NE}, \mathrm{ENE}, \mathrm{E}$ (山棐主風)，の亚年からの平均気温僻善 は $-1.17^{\circ} \mathrm{C} て ゙, \mathrm{SW}, \mathrm{WSW}, \mathrm{W}$ (䛿西主風)のそれの $+3.72^{\circ} \mathrm{C}$ より約 $5^{\circ} \mathrm{C}$ 低温で点る。

（3）天気 天気を快腈, 腈, 薄㬡（高是を含光, 以 下同じ）㬡，雨，霧の6 種に分けると風向每の出現数が 少いので, 頻度の多い前記两主風の和について天気毎の 出現数と天気比率（同一風向の全日数に対する各天気の 日数の割合) を示すと第 3 図のようになり出現数は各天 気其山背風の方が多い。然し天気の割合は山背主風の方

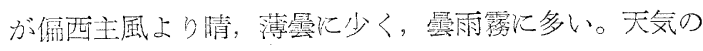

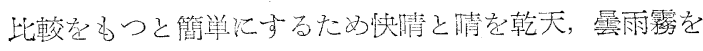
湿天（薄量恎中間に当るので除いた）とすると，下表か ら明かなように山背風は愠西風より的 $10 \%$ 乾天が少く， 湿天が多いことになり， 天氮比率 山背風は湿陰であること が分る。

次に乾, 湿天の月によ る変移を示与と第 4 図の

\begin{tabular}{c|l|l}
\hline 風 & 乾 天 & 湿 天 \\
\hline 山背主風 & $35.7 \%$ & $45.6 \%$ \\
偏西主風 & 47.5 & 35.3 \\
\hline
\end{tabular}
ようになり，4〜6月及び9月は山背風と偏西風の差が 大きいが，8月は両者活淩等しいことが分る。 


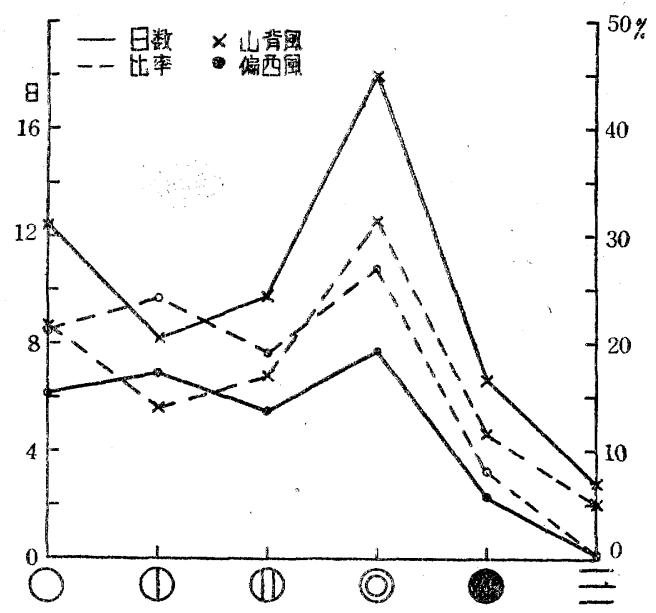

第3図山背, 偏西两主風の天氛日数と比率

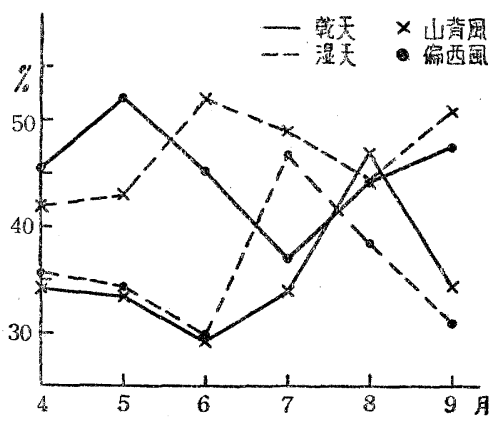

第 4 図 天笭比率の月变化

（4）湿度 気温と同様等日の平年值の 5 日移動平

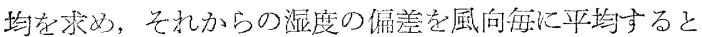
第2図の破線のようになり，NNW-(E)-SEの間で湿 度の高いことが分る。前透の雨主風の平均混度の差は 17.6\%で市る。

（5）日照時数 日照時数は㡺間の天気によつて決 定されるのであるが，午前 10 時の天気と日照時数との 間に高い相関があれば風向による日照の多璂を知ること が出来る。

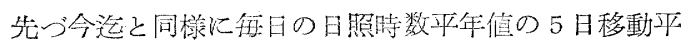

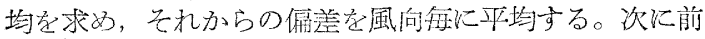
記の車主風の月合計の腈比率の 1/2 と快情比率の和（快 睛と睛の日の日照時数の割合が $2: 1$ と仮定した）を4 月から 9 月まで求め, 雨者の相関係数を求めると十0.75 になり，かなり高い相関が認められるので，風向別日照 時数偏差学求めても差支ない:思われる。これを図示す ると第 1 図破線のよ5になり概して低温風の方が璂照で ある。然し山脩主風である NE， ENE では日照が多い。 これは海風が含をれているためではないかと思われる。

\section{3. 山背風の風向範国亡気候特性}

前章の 5 月から 8 月をでの平均風向別気爱から知られ た山背風の平年の風向範囲と気候特性は次の通りで岀 る。

（1）気温, 湿度から考察すると山背風の平均の風向 範囲は NNW- $\mathrm{N}$ - - SE と思方れる。

（2）山背主風は偏西主風より平均約 $5 \circ \mathrm{C}$ 低温であ る。

（3）山背主風は偏西主風より平均約 $18 \%$ 高湿であ る。

（4）山背風は各天気共㣂西風より頻度が多いが，天 気の割合は山背風の力が熖西風より墨雨霧に多く, 腈薄 暴に少い。乾, 湿天で比較すると山背主風は偏四主風よ り約 $10 \%$ 乾天が少く湿天が多い。

（5）日照は山背風域では概して寡照で要るが山背主 風である $\mathrm{NE}, \mathrm{ENE}$ に多照である。これは海風が含ま れているためと思われるので更に研究中である。

\section{4. 山背風と凶冷との関係}

各風向の風が平均の気温併差で吹くとすれば，月平场 気温は各風向の頻度分存によつて決定される。例えば山 背風が多く吹けげ月平均気温は低下寸る。

今市る月の風向 $d$ にお汁る平均の気温偏差を $\Delta \theta_{d}$ と

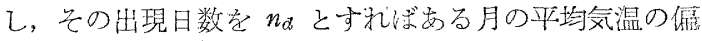
差 $\Delta \theta_{a}$ は次式で表わされる。

$$
\begin{aligned}
& \Delta \theta_{d}=\frac{\sum_{a}\left(\Delta \theta_{d} \cdot n_{d}\right)}{n} \ldots . \\
& d: 16 \text { 方位々静穞 } \\
& n=\sum_{a} n_{d}: \text { 月の総月数 }
\end{aligned}
$$

(1) 式で計算した $\Delta \theta_{a}$ と実際の月平均気温僱差 $\Delta \theta_{a}$ を 第 5 図に示す。同図には凶年の代表として昭和 16，20 年, 鄷年の代表と乙て四和 25 年, 平年として昭和 13 年 を載せ心。氷稻の作沉指数は昭和 16,20 年を除く昭和 11 年から 25 年末での平均值に対するもので岕る。6 月 から9月末で平年より高温が続けば大体豊作で, 平年作 の年は時に高低があるも，月平均で $3^{\circ} \mathrm{C}$ 以上低くなるこ とは殆どない。凶年の伯和 16 年は 7,8 月に开年より $4^{\circ} \mathrm{C}$ 以上低く, 昭和 20 年も 5 月から 9 月末で低温で特 に7月は $4^{\circ} \mathrm{C}$ 以上低温であつた。このように大莋の年 は 7 月 8 月の気温が著しく低く且低温に持続性がある。

$\Delta \theta_{a}$ そ $\Delta \theta_{a}$ とを比較してみると, 平年は両者の差が一 般に少く正負が入り交つている。豊年は4月から9月支 で殆ど $\Delta \theta_{d}$ の方が高めであるが，凶冷年に虫逆に $3^{\circ} \mathrm{C}$ 以 上低い月があり 5〜8 月を通して低めに経過している。 


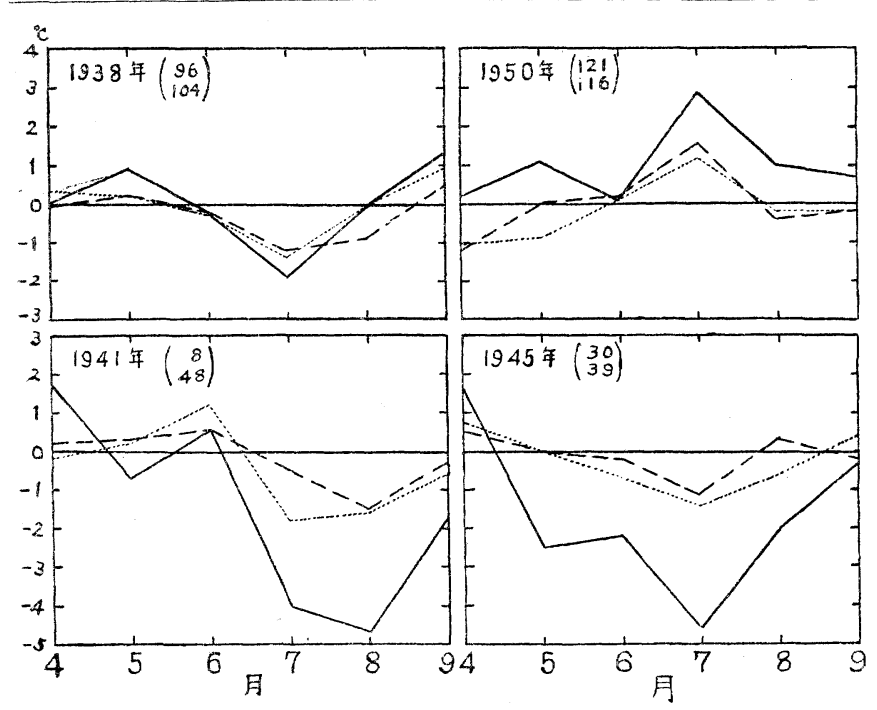

第 5 図気温偏差図実線は実測值 $\left(\overline{\Delta \theta_{a}}\right)$, 破線は $\Delta \theta_{d}$,

点線は $\Delta \theta_{u}$ を示す。（）内の数字は上行が上北郡，下

行が全県の水稲作況指数である。

この大きな差黑の原因としては平均の気団の温度が低い か, 悪天殹が多いとい5ことが考えられる。後者の影響 をみるためには風向別天気別の亚均気温偏差を知る必要 が㐫るが, 統計数が少いので一広風向を山背風 (NNW〜 SE）及び静稳を含さ他の風向に分け，天気を快辕，晴，

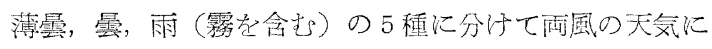
よる亚年からの平均気温偏差を求か, これに各年各月の 出現日数を采ずると，風と天気によつて被正された月平 均気温偏差, 即占

$$
\Delta \theta_{w}=\frac{\left(\sum_{w} \Delta \theta_{w} \cdot n_{w}\right)_{\mathrm{E}}+\left(\sum_{w} \Delta \theta_{w} \cdot n_{w}\right)_{\mathrm{W}}}{n} \cdots \cdots(2)
$$

が求められる。ここに $\Delta \theta_{w}$ は風別天気別平均気温偏差, $n_{v}$ は風別天気日数， $n$ は月総日数， $\mathrm{E}, \mathrm{W}$ は夫々山背 風，その他の風を表わす。これを図示すると第 5 図点線
のようになり，佮凶冷時には $\Delta \theta_{a}$ の方が著し く低い。佮山背風の継続日数によつて子気温 に影幦を及ぼすが3)，これについては別の機 会に簤り，今は一応この差が気団の低温によ るものと考光て扮く。即占風向別の頻度と天 気日数の, 平年からの偏差が気温に及ぼす影 響は月平均土 $2^{\circ} \mathrm{C}$ 以内で, 凶冷は気団の温度 が平均して平年より著しく低いことによつて 起るるのと思われる。

\section{5. 結 語}

八戸測候所の午前 10 時の 15 ケ年間の暖侯 期の気象を風向每に分け, 風向による気象の 変化から 5〜8月の平均の山背風の風向範囲 そ気象特性がかなり明かになつた。山背風と 凶泠との関係については，凶冷は山背風の頻 度や婁天侯によるよりは寧万気団温度の低い ことによつて起るものと思われる。何山背風 と海風の分離, 凶冷の解䄬について研究を継続中であ る。

終りに本研究に助力された農業気皇科の小田桐光雄, 津 川清治, 王田スエの諸氏に感謝の意を表する次第である。

\section{参教交献}

1) 木村吉郎：昭和 24 年夏季の青森景に和汇る漏東 風について, 昲業気象 $6(3.4) 1951$.

- : 偏東風の地域的婂向について, 同誌 7 (1) 1951 .

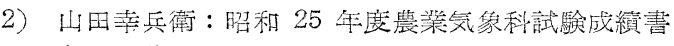
(滕军刷) 青森農試, 1951.

: 昭和 26 年度山背風研究成績 (滕写 刷) 青森農試, 1952 .

3) 門脇倒郎：山背風，東北の気候， $72 ， 1951$.

\section{Résumé}

In Aomori prefecture the prevailing north-easterlies have been named "Yamase-winds". In warm period they accompany the cold and bad weather, and so great concern has been given them from the standpoint of agriculture.

The authors classified the wind directions of 10.00 JST observed at Hachinohe Weather Station for the five months from April to September, for the period of 1937 1951 and made some statistical study.

A. The range of wind direction and climatic characters of Yamase winds from May to August are as follows :

(1) The wind direction ranges from NNW to SE including E.

(2) The principal winds of Yamase (NE, ENE, E) are about $5^{\circ} \mathrm{C}$ lower that of prevailing westerlies (SW, WSW, W) and about $18 \%$ wetter in relative humidity.

(3) Yemase-winds are more frequent than the westerlies in all kinds of weather, but the percentage of occurrence of low cloud overcast, rainy and foggy days for the Yamase-winds is greater than that for the westerlies and vice versa for the percentage of occurrence of fine and high and 
middle cloud overcast days.

(4) The duration of sunshine is generally shorter for Yamase than the westerlies, but in NE and ENE-winds, sunshine is more abundant in Yamase. This may be because of the direction of the sea breezes being included in the range of Yamase-winds.

B. The relation between notable low temperatures and Yamase-winds. The monthly mean air tempertures corrected by the deviation of wind direction are obtained from the formula $(1)\left(\overline{\Delta \theta_{d}}, n_{d}\right.$ are mean air temperature departures and number of days for each direction. $n$ is number of days a month.) and shown by the broken lines in Fig. 5. In the year of bad harvest the actual air temperature departures (full line) are $2 \sim 3^{\circ} \mathrm{C}$ lower than the former. It is considered that these differences are due to the kind of air mass or bad weather.

In order to see the effect of bad weather the wind directions are classified into two groups, the Yamase winds $(\mathrm{NNW} \sim \mathrm{SE})$ and other winds including calm, and the kinds of weather are classified into five groups, clear, fine, high and middle cloud overcasts, low cloud overcast and rain including fog. Then the monthly mean temperature departures corrected according to weathar and wind direction are obtained by the formula (2) $\left(\Delta \theta_{w}, n_{w}\right.$ are mean temperature departures and number of days for each kind of weather for each wind direction) and are shown by the dotted lines in Fig. 5. During the summers of 1941 and 1945, the monthly mean temperatures are much lower than these values. Therefore, it is considered that these notable low temperatures are due to the cold air mass.

\section{本会記 事}

\section{九州交部総会開かる}

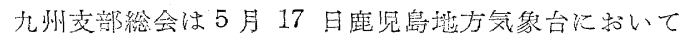

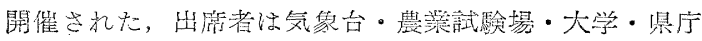
蓄蕒など各分野に啮り約 50 名が参集し終日，熱心な討

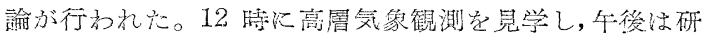
究発表に引続いて風水窨のシン年ジュームがあり, 最後 に横尾幹票（管区）の閉会のあいさつがあつて, 想親会 を行い終了したのは20睈でろであつた。また 18 日は

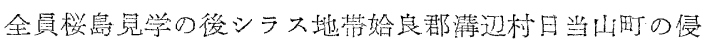
飿の現場を視察した。

な打当日の研究会次䈍は次のと招りである。

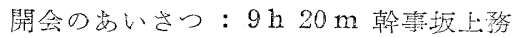

岗い岂つ：卖部長 倉石六郎

研究発表 : $9 \mathrm{~h} 30 \mathrm{~m} \sim 11 \mathrm{~h} 20 \mathrm{~m}$

1. 梅雨の夕晴化ついて 茶屋道久吉（枕陭測）

2. 南九州の畑地带に和沙る雨水の流去並び滲透 について 回辺邦英（㗬崎大）

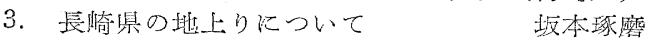
(長踦海洋)

4. 耕地汇対与る防風林の投影（宮崎市の計画例）

見学：解説 高層気象観測の現状 佐藤正一（九州農試）

舅測完学 甲南高校屋上 新井重男（庇罯島気）

5. 暖地水田用水量の実驗的研究 佐藤正一・船楅義成（九州農試）
6. 人工隆雨の実釦 坂上 務 (九穴豊)

7. 新案自記蒸発計とその観測について シンポジューム（風水害について）： 武田京一（九大農）

1. 九州飞和汁る雨の強さ 横尾多美男・田烟七郎（福風気）

2. シラス坡带に打计る水䞏気策学的調查

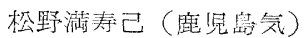

3. シラスの浸蝕について 西 力造（鹿児島大）

4. 管崎県の䖝寒調查比ついて

閉会のめいさっ：幹事 横尾多美男

村瀬英武（宮崎農試）

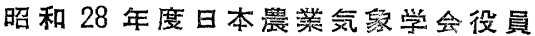

\section{会長鈴木漟太郎}

評議員 ( $\mathrm{A} B \mathrm{~B}$ 順) 大後美呆 檀上哲郎 福目仁

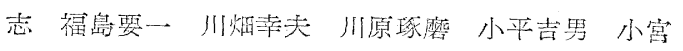
書之助 久保路夫日下部正雄松野蔽寿已松尾欽 二三原義秋 萀回快夫 佐藤正一鈴木親卦 日口 亮平 高須謭一 武田京一 玶井八十二 横尾多美男 横山偉和夫 内海德太郎

支部長 (北海道)八鍁利助 (東北)間野 浩 (関東) 小平吉男（信州）公木誠政（近畿）滑川忠夫（中・四 国)仁科伸彦 (九州)倉石六郎

幹 專 日下部正雄 坪井八十二 矢吹万寿 小沢行雄

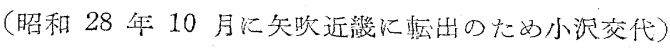

